\title{
Tissue extraction of DNA and RNA and analysis by the polymerase chain reaction
}

\author{
D P Jackson, F A Lewis, G R Taylor, A W Boylston, P Quirke
}

\begin{abstract}
Several DNA extraction techniques were quantitatively and qualitatively compared using both fresh and paraffin wax embedded tissue and their suitability investigated for providing DNA and RNA for the polymerase chain reaction (PCR).

A one hour incubation with proteinase $K$ was the most efficient DNA extraction procedure for fresh tissue. For paraffin wax embedded tissue a five day incubation with proteinase $K$ was required to produce good yields of DNA. Incubation with sodium dodecyl sulphate produced very poor yields, while boiling produced $20 \%$ as much DNA as long enzyme digestion. DNA extracted by these methods was suitable for the PCR amplification of a single copy gene. Proteinase $\mathrm{K}$ digestion also produced considerable amounts of RNA which has previously been shown to be suitable for PCR analysis. A delay before fixation had no effect on the amount of DNA obtained while fixation in Carnoy's reagent results in a much better preservation of DNA than formalin fixation, allowing greater yields to be extracted.
\end{abstract}

The molecular biological analysis of disease processes requires the extraction of DNA and RNA from a variety of tissue preparations, including fresh and paraffin wax embedded material. The extraction of nucleic acids from routinely fixed and processed tissue is particularly important as it permits the use of archival material for the retrospective investigation of disease.

Techniques for the extraction of DNA from fresh tissue and cytological preparations have been amply described ${ }^{12}$ and since adapted for use with paraffin wax embedded tissue. The disadvantage is that these methods require large amounts of tissue to produce sufficient DNA suitable for analysis by standard molecular biological procedures. ${ }^{34}$

RNA is highly labile and ribonucleases (RNAses) are endogenous in tissues and ubiquitous in the environment and therefore require more complex extraction methods. ${ }^{5}$ These have not been described for use with fixed, processed material.

Fixation and embedding of tissue is a procedure that has a profound effect on its molecular arrangement. It is therefore necessary to investigate what effect this processing has on the ease with which DNA can be extracted from tissue.
The polymerase chain reaction (PCR) is a rapid technique for the enzymatic, in vitro amplification of DNA, ${ }^{6}$ or RNA, by the addition of a reverse transcription step. ${ }^{78}$ The technique is very sensitive and can tolerate small quantities of poor quality template DNA or RNA. This has important implications as it may permit the use of very rapid simple DNA and RNA extraction techniques to provide material for PCR analysis.

We performed a quantitative and qualitative study, comparing several reported DNA extraction procedures for use with both fresh and paraffin wax embedded tissue, and investigated their suitability to provide DNA and RNA for PCR. We also investigated different aspects of tissue fixation and processing to determine their effects on DNA extraction.

\section{Methods}

Fresh tonsil, obtained immediately after removal, was used as a model tissue for DNA extraction experiments. The tissue was cut into $100 \mathrm{mg}$ blocks for comparative experiments, or blocks suitable for sectioning, and either frozen in liquid nitrogen or fixed and then processed on a Shandon 2LE automatic tissue processor before being embedded in paraffin wax. Cryostat frozen sections $(8 \mu \mathrm{m})$ or paraffin wax embedded sections $(4 \mu \mathrm{m})$ were cut on to glass slides. Tissue was fixed in $4 \%$ formaldehyde (tap water formalin), neutral buffered formalin, formol sublimate, paraformaldehyde or Bouin's reagent. ${ }^{9}$ Archival splenic tissue was obtained from the archives of the Department of Pathology, University of Leeds.

Owing to the impossibility of absolute control over variables such as cellularity, area, and thickness within fresh and paraffin wax embedded tissues, together with the amount of tissue required for all of the different studies performed, different blocks of tissue were used for each experiment. Tonsilar or splenic tissue was used throughout, the blocks of which were cut on the same microtome where possible. Serial sections were always used and taken from the same blocks of tissue for comparison. When weight of tissue was used blocks were taken from the same tonsil. Each extraction procedure was routinely performed on 10 tissue sections.

\section{DNA ASSAYS}

Extracted DNA samples were assayed quantitatively using the TKO-100 dedicated minifluorometer (Hoefer Scientific Instruments, San Francisco, USA) which measures the 
fluorescence of Hoescht 33258 (Polysciences, Warrington, Philadelphia) in the presence of DNA. Human placental DNA (Clontech Laboratories, Palo Alto, California, USA) at $100 \mathrm{ng} / \mu \mathrm{l}$ was used to calibrate the minifluorometer.

The quality of the DNA was determined by running samples on a $0.7 \%$ agarose electrophoresis gel (Seakem GTG, FMC bioproducts, Uppsala, Sweden), stained with ethidium bromide (Sigma, Uppsala, Sweden), in TRIS-acetate EDTA (TAE) buffer in a GNA-100 electrophoresis cell (Pharmacia, Uppsala, Sweden) at $50 \mathrm{~V}$ for 10 minutes and $100 \mathrm{~V}$ for one hour. A $\lambda$ DNA Hind $I I I$ digest (BRL) provided a standard, with a ladder of fragments: 23130 base pairs, 9416 base pairs, 6562 base pairs, 4368 base pairs, 2322 base pairs, 2027 base pairs, 564 base pairs and 125 base pairs.

\section{DNA EXTRACTION}

Three methods were investigated: proteinase $\mathrm{K}$ incubation modified from the method of Strauss ${ }^{1}$ and sodium dodecyl sulphate (SDS) incubation, and boiling tissue modified from the method of Lench et al. ${ }^{10}$

\section{Proteinase K incubation}

Frozen fresh tissue blocks were crushed to a fine powder using a mortar and pestle and then suspended in $1.2 \mathrm{ml} / 100 \mathrm{mg}$ tissue of digestion buffer $(100 \mathrm{mM} \mathrm{NaCl}, 10 \mathrm{mM}$ TRIS-Cl, $25 \mathrm{mM}$ EDTA, $0.5 \%$ SDS, pH8.4), containing $0.1 \mathrm{mg} / \mathrm{ml}$ proteinase $\mathrm{K}$ (Sigma). Paraffin wax embedded sections were dewaxed in warm xylene and rehydrated by passage through graded alcohols. The sections were then scraped into microfuge tubes, suspended in digestion buffer (about $200 \mu \mathrm{l} / 10$ sections), and incubated at $37^{\circ} \mathrm{C}$ for a variable period. Nucleic acid was purified by an organic extraction step. An equal volume of phenol:chloroform isoamyl alcohol (25:24:1) was added to the proteinase $\mathrm{K}$ digests, mixed thoroughly, and centrifuged to separate the aqueous and organic layers. The upper aqueous layer containing the nucleic acid was collected and the extraction repeated. A final extraction was carried out using an equal volume of chloroform:iso-amyl alcohol (24:1). The nucleic acid was then precipitated with two volumes of cold ethanol $\left(-20^{\circ} \mathrm{C}\right)$ and one tenth volume $3 \mathrm{M}$ sodium acetate $(\mathrm{pH} 5 \cdot 2)$ at $-20^{\circ} \mathrm{C}$ for one hour, spun down (13000 rpm, for 10 minutes, dried, and redissolved in TRISEDTA buffer for between three and five days.

\section{SDS incubation}

The tissue was prepared as above, but suspended in $1 \%$ SDS (about $200 \mu \mathrm{l} / 10 \mathrm{sec}$ tions) and incubated at $50^{\circ} \mathrm{C}$ for between one and four hours. The nucleic acid was then purified by phenol/chloroform extraction and ethanol precipitation.

\section{Boiling}

The tissue was suspended in distilled water (about $500 \mu \mathrm{l} / 10$ sections) and boiled for a variable time in the Perkin-Elmer Cetus (PEC, Norwalk, Connecticut, USA) Thermal cycler.
The resulting solution was used directly for analysis.

\section{RNASE/DNASE DIGESTION}

Extraction nucleic acid samples were digested with deoxyribonuclease (DNAse) and ribonuclease (RNAse). RNAse A (Sigma) was dissolved in SSC $(0.3 \mathrm{M}$ sodium citrate, $30 \mathrm{mM}$ sodium citrate, $\mathrm{pH} 7 \cdot 0$ ) to a concentration of $10 \mathrm{mg} / \mathrm{ml}$. This was boiled for 10 minutes to destroy any DNAse activity and then diluted to $200 \mu \mathrm{g} / \mathrm{ml}$ with SSC. RNAse $\mathrm{T}_{1}$ (Sigma) was added to a final concentration of $200 \mu / \mathrm{ml}$. DNAse I (Sigma) was dissolved in $0.01 \mathrm{M}$ TRIS-Cl containing $0.01 \mathrm{M} \mathrm{MgCl}_{2}$ and then diluted down to $200 \mu \mathrm{g} / \mathrm{ml}$. A $10 \mu \mathrm{l}$ aliquot of each DNA sample was incubated with an equal volume of each enzyme preparation for one hour at $37^{\circ} \mathrm{C}$ and the undigested nucleic acid purified by phenol/chloroform extraction and ethanol precipitation. The samples were analysed by gel electrophoresis (as above).

\section{POLYMERASE CHAIN REACTION}

Two primers for the human factor VIII gene were used." Fifty picomoles of each were incubated with $1 \mu \mathrm{l}$ of extracted DNA sample in $25 \mu \mathrm{l}$ of $1 \times$ PCR buffer $(50 \mathrm{mM} \mathrm{KCl}$, $10 \mathrm{mM}$ TRIS-Cl, $1.5 \mathrm{mM} \mathrm{MgCl}_{2}, 0.01 \%$ gelatin, $\mathrm{pH} 8.3$ ) for five minutes at $94^{\circ} \mathrm{C}$ in the PEC Thermal cycler to denature fully the template DNA and to inactive any proteases contaminating the DNA before Taq polymerase was added. To this was added $25 \mu \mathrm{l}$ of $1 \times$ PCR buffer, containing $2.5 \mathrm{U}$ of "Ampli Taq" (Cetus) and $0.4 \mathrm{mM}$ each of dATP, dCTP, dGTP and dTTP. The reaction mixture was then incubated for 40 cycles of 48 seconds at $94^{\circ} \mathrm{C}, 48$ seconds at $50^{\circ} \mathrm{C}$, and one minute at $72^{\circ} \mathrm{C}$, followed by 10 minutes at $72^{\circ} \mathrm{C}$ to ensure that all the product was fully extended. Each PCR experiment included a negative control of distilled $\mathrm{H}_{2} \mathrm{O}$ in place of DNA. The PCR products were analysed by running on a $2^{\circ}{ }_{0}$ agarose electrophoresis gel, stained with ethidium bromide in a DNA subcell (BioRad) at $150 \mathrm{~V}$ for one and a half hours. A 123 basepair ladder (BRL) was used as a standard.

\section{Results}

\section{FRESH TISSUE}

$D N A$

Reproducibility: The accuracy of repeat extractions of DNA was assessed both on blocks and sections of fresh tissue. Twelve tissue block samples and 12 sets of 10 frozen sections were extracted by proteinase $K$ incubation. The mean yield and standard deviation for blocks was $6.88(1.60) \mu \mathrm{g} / \mathrm{mg}$ and for tissue sections $12.51(2.73) \mu \mathrm{g} / \mathrm{mg}$, confirming the validity of using duplicate or triplicate samples.

Proteinase $K$ : Most protocols for the extraction of DNA from fresh tissue or cultured cells require tissue to be incubated with proteinase $\mathrm{K}$ for $12-24$ hours. $^{1}$ An incubation time of 18 hours for the proteinase $\mathrm{K}$ extraction technique was a very efficient procedure, capable of extracting high molecular weight DNA (more than 20 kilobases) from as little as one frozen section of fresh tonsil. Decreasing the time to 
Figure $1 \quad 0.7 \%$ agarose electrophoresis gel of extracted DNA samples. (a) DNA from fresh frozen tonsil sections, extracted by different methods. (1) Standard גDNA Hind III digest; (2) proteinase $K$ incubation (18 hours); (3) proteinase $K$ incubation (one hour); (4) SDS incubation (one hour); (5) boiling (15 minutes).

(b) DNA from paraffin wax embedded tonsil sections extracted by different methods: (1) proteinase $K$ incubation (five days);(2) SDS incubation (one hour); (3) boiling (15 minutes); (4) standard $\lambda D N A$ Hind III digest.

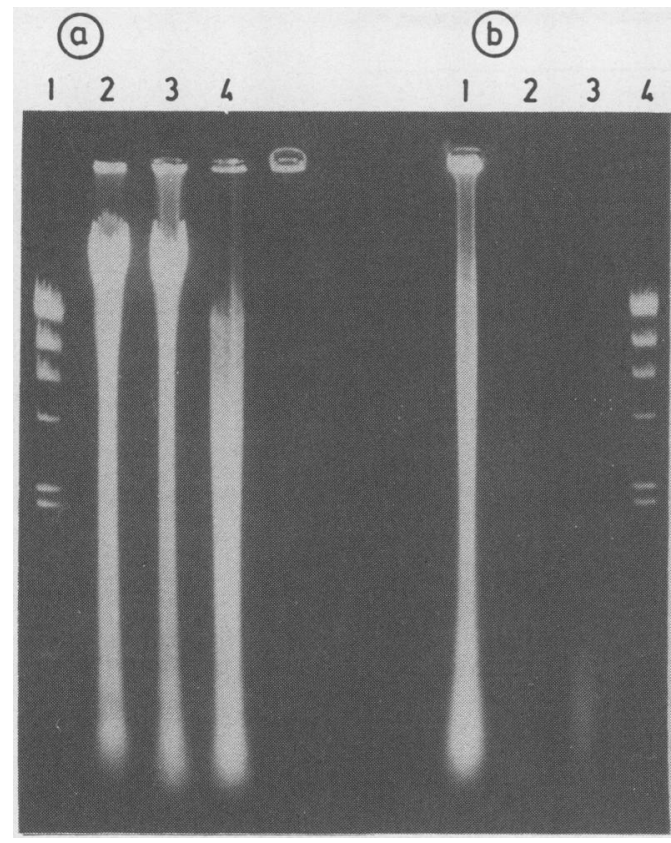

just one hour did not significantly reduce the amount of DNA recovered, nor did lengthening the incubation time to five days. For this method, a proteinase $\mathrm{K}$ concentration of $0.1 \mathrm{mg} / \mathrm{ml}$ was most efficient.

$S D S$ : The extraction of DNA from a cell pellet by a short (one to two hours) incubation with $1 \%$ SDS has been described. ${ }^{10}$ When applied to fresh frozen sections, this method produced relatively poorer yields than the proteinase $K$ incubation method. These were only marginally improved by increasing the incubation to four hours.

Boiling: Boiling the cell pellet has also been described as an extraction method for fresh cytological preparations. ${ }^{10}$ Using this method on frozen tissue, the optimal conditions were boiling sections for just $10-15$ minutes as increasing the boiling time reduced the yields of extracted DNA.

Comparison of fresh tissue DNA extraction techniques: A separate experiment was performed to permit direct quantitative and qualitative comparison of these different procedures for the extraction of DNA from fresh frozen tissue sections (table 1, fig 1a). This showed that a one hour incubation with proteinase $\mathrm{K}$ produced high yields of high molecular weight DNA compared with the poorer yields of low molecular weight DNA (less than 9 kilodaltons) produced by SDS incubation and the small amounts of fragmented DNA from boiled tissue.

\section{$R N A$}

The low molecular weight material produced

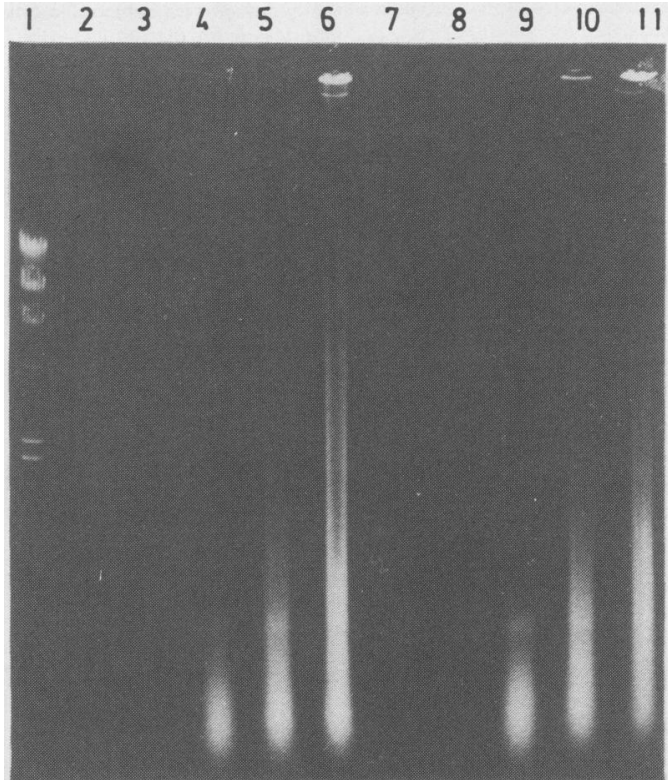

Figure $2 \quad 0.7 \%$ agarose electrophoresis gel of DNA samples extracted from waxed or dewaxed sections of paraffin wax embedded tonsil by different length incubations with proteinase $K$.

(1) Standard: $\lambda D N A$ Hind III digest.

Waxed: (2) one hour; (3) three hours; (4) 24 hours; (5) 48 hours; (6) five days. Dewaxed: (7) one hour; (8) three hours; (9) 24 hours; (10) 48 hours; (11) five days.

by these extraction procedures from fresh tissue may contain contaminating RNA as well as fragmented DNA. Digestion with RNAse showed that both the one hour and 18 hour proteinase $\mathrm{K}$ incubations produced substantial amounts of RNA; SDS incubation also produced some RNA; while the small amount of low molecular weight material produced by boiling was no longer visible on electrophoresis after digestion with either DNAse or RNAse, suggesting that this contained both RNA and fragmented DNA.

\section{PARAFFIN WAX EMBEDDED TISSUE}

\section{DNA}

The same procedures as above were investigated with paraffin wax embedded tissue sections.

Proteinase $K$ : For paraffin wax embedded material, increasing the length of incubation with the enzyme substantially improved the yield of DNA. A five day incubation produced almost 10 times as much DNA as an overnight incubation (table 2), with a corresponding increase in the molecular weight of the extracted DNA (fig 2). A long proteinase $\mathrm{K}$ digestion was also capable of extracting DNA from a single section of paraffin wax embedded tissue. Dewaxing the tissue in xylene had no effect on

Table 1 DNA yield from $100 \mathrm{mg}$ blocks of fresh tonsil, extracted using different optimised protocols

\begin{tabular}{|c|c|c|c|c|}
\hline & Proteinase $K$ & Proteinase $K$ & SDS incubation & Boiling \\
\hline & (1 hour) & (18 hours) & (1 hour) & (15 minutes) \\
\hline $\begin{array}{l}\text { Mean DNA yield } \\
(\mu \mathrm{g} / \mathrm{mg}) \\
\text { values } \\
\text { Mean yield as a percentage } \\
\text { of most efficient method }\end{array}$ & $\begin{array}{l}\quad 5 \cdot 45 \\
(5 \cdot 1,5 \cdot 5,5 \cdot 76) \\
100\end{array}$ & $\begin{array}{l}5 \cdot 17 \\
(4 \cdot 22,5 \cdot 62,5 \cdot 66) \\
94 \cdot 9\end{array}$ & $\begin{array}{l}0 \cdot 79 \\
(0 \cdot 653,0 \cdot 936,0 \cdot 786) \\
14 \cdot 5\end{array}$ & $\begin{array}{l}0.58 \\
(0 \cdot 616,0 \cdot 211,0.924) \\
10 \cdot 6\end{array}$ \\
\hline
\end{tabular}

$\mathrm{n}=3:$ values in parentheses 

Table 2 DNA yield from sections $\dagger$ of paraffin wax embedded tonsil, waxed or dewaxed in xylene,
extracted by varying lengths of proteinase K incubation

\begin{tabular}{lll}
\hline & \multicolumn{2}{l}{ Mean DNA yield $(\mu \mathrm{g} /$ section $)$} \\
\cline { 2 - 3 } Length of incubation $\left(37^{\circ} \mathrm{C}\right)$ (hours) & Waxed & Dewaxed \\
\hline 1 & $0 \cdot 06(0 \cdot 02,0 \cdot 03,0 \cdot 14)$ & $0 \cdot 03(0 \cdot 01.0 \cdot 03.0 \cdot 04)$ \\
3 & $0 \cdot 04(0 \cdot 025,0 \cdot 04,0 \cdot 05)$ & $0 \cdot 07(0 \cdot 05,0 \cdot 07,0 \cdot 08)$ \\
24 & $0 \cdot 22(0 \cdot 16,0 \cdot 22,0 \cdot 27)$ & $0 \cdot 27(0 \cdot 14,0 \cdot 31,0 \cdot 35)$ \\
48 & $0 \cdot 72(0 \cdot 44,0 \cdot 77,0 \cdot 95)$ & $0.95(0 \cdot 51,1 \cdot 14,1 \cdot 21)$ \\
120 & $2 \cdot 09(1 \cdot 29,2 \cdot 30,2 \cdot 67)$ & $2 \cdot 10(1 \cdot 49,2 \cdot 30,2 \cdot 52)$ \\
\hline
\end{tabular}

$\mathrm{n}=3$ values in parentheses.

†Ten serial sections from the same block of tissue.

the yield or quality of the DNA (table 2 , fig 2 ). $S D S$ : Increasing the digestion time from one to 4 hours did not improve DNA yields.

Boiling: Increasing the boiling time made no appreciable difference to the DNA yield.

Comparison of paraffin embedded tissue DNA extraction techniques: A five day proteinase $\mathrm{K}$ incubation produced greater yields than SDS incubation, but the simple rapid boiling method produced one fifth as much DNA as the long enzyme incubation (table 3 ). The DNA extracted by proteinase $\mathrm{K}$ was of a high molecular weight, while the SDS and boiling methods produced lower molecular weight and fragmented DNA. Some of the DNA extracted by boiling remained in the loading well of the electrophoresis gel, suggesting that it may have remained partially associated with protein (fig 1b).

\section{$R N A$}

After digestion with either RNAse or DNAse the small amount of low molecular weight material extracted from paraffin wax embedded tissue by SDS, incubation, or boiling was no longer visible on gel electrophoresis, again suggesting that they contained both RNA and fragmented DNA. RNAse digestion of the sample produced by proteinase $\mathrm{K}$ incubation, however, showed that this procedure produced relatively large amounts of RNA.

\section{DNA PCR}

The DNA extracted from routinely processed spleen by all of the extraction methods was of a quality suitable for amplification by the polymerase chain reaction. The DNA samples were of a sufficient concentration such that $1 \mu \mathrm{l}$ of each could be used as template for amplification, producing a 142 base pair fragment of the factor VIII gene (fig 3, lanes 2, 4, 5). The extracted DNA sample from the spleen using proteinase $\mathrm{K}$ was of a very high concentration (980 $\mathrm{ng} / \mu \mathrm{l})$, and from this and other results (not shown) it seems that adding more than $500 \mathrm{ng}$ of DNA as the PCR template may actually inhibit the amplification reaction. Adding one tenth of the DNA (98 ng)

Table 3 DNA yield from sections $\dagger$ of paraffin wax embedded tissue extracted using different optimised protocols

\begin{tabular}{|c|c|c|c|}
\hline & $\begin{array}{l}\text { Proteinase } K \\
\text { ( } 5 \text { days) }\end{array}$ & $\begin{array}{l}\text { SDS incubation } \\
\text { (1 hour) }\end{array}$ & $\begin{array}{l}\text { Boiling } \\
\text { (15 mins) }\end{array}$ \\
\hline \multirow{2}{*}{$\begin{array}{l}\text { Mean DNA yield }(\mu \mathrm{g} / \text { section })(n=2) \\
\text { Values } \\
\text { Mean yield as a percentage of most } \\
\text { efficient method }\end{array}$} & $\begin{array}{l}1 \cdot 75 \\
1 \cdot 84,1 \cdot 65\end{array}$ & $\begin{array}{l}0.088 \\
0 \cdot 05,0 \cdot 125\end{array}$ & $\begin{array}{l}0 \cdot 325 \\
0 \cdot 33,0 \cdot 32\end{array}$ \\
\hline & 100 & 5 & 18.6 \\
\hline
\end{tabular}

†Ten serial sections from the same block of tissue.

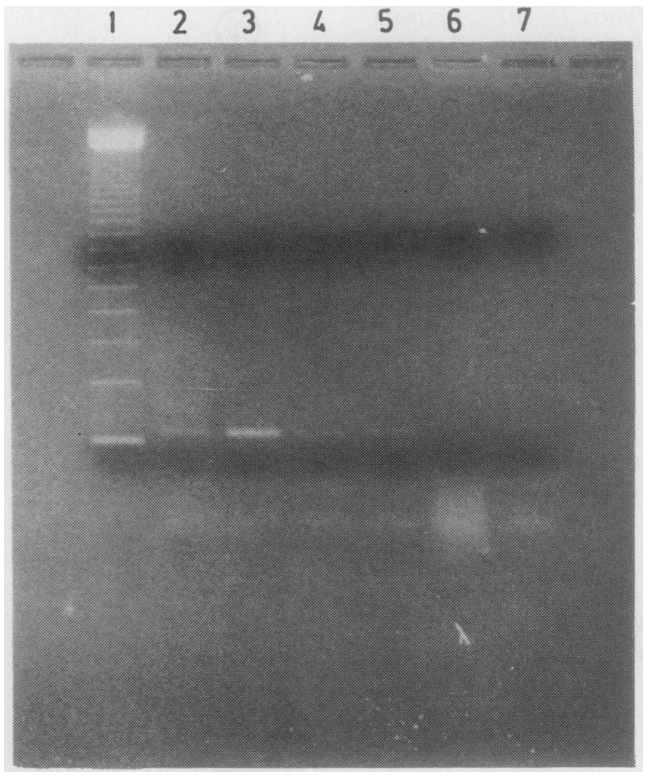

Figure $32 \%$ agarose electrophoresis gel of PCR products, showing amplification of 142 base pairs fragment of FVIII gene from DNA extracted from paraffin wax embedded sections of spleen tissue by different methods.

(1) Standard: 123 base pair ladder, (2) proteinase $K$ incubation (five days); (3) $1 / 10$ dilution of proteinase $K$ sample; (4) SDS incubation (one hour); (5) boiling (15 minutes);(6) intact, undigested, dewaxed section; (7) negative control: distilled water.

produced a much brighter more distinct PCR product band (fig 3, lane 3), compared with the fainter band and non-specific smear when using larger amounts of template (fig 3, lane 2). Amplification of the factor VIII gene was also attempted using an intact, non-digested, dewaxed section of paraffin wax embedded spleen as template. This reaction did not produce the factor VIII specific 120 base pair fragment (fig 3, lane 6).

\section{FIXATION}

Blocks of fresh tonsil were left in sealed containers at room temperature for up to seven days before fixation for 24 hours in $4 \%$ formaldehyde, and the DNA extracted using an overnight proteinase $\mathrm{K}$ incubation. Surprisingly, the yields obtained did not decrease with an increasing delay before fixation, suggesting that leaving tissue unfixed for up to seven days caused only a negligible degradation of DNA, compared with the fixation process itself. Fresh tissue produced almost 40 times as much DNA $(5.014 \mu \mathrm{g} / \mathrm{mg})$ as tissue fixed immediately in $4 \%$ formaldehyde for 24 hours $(0.135 \mu \mathrm{g} / \mathrm{mg})$, and the DNA was of very high molecular weight, compared with the fragmented material extracted from fixed tissue.

Leaving tissue in fixation for an extended period (up to 12 weeks), resulted in a further decrease in the amount of DNA that could be extracted (fig 4). After an initial 24 hours' fixation at $37^{\circ} \mathrm{C}$, however, the yields of RNA extracted after two to three weeks in fixative were much higher than if the fixative was kept at room temperature, while stronger heating (up to $60^{\circ} \mathrm{C}$ ) during the first 24 hours resulted in much poorer yields of DNA. After 12 weeks 
Figure 4 Yield of DNA extracted from $100 \mathrm{mg}$ of tonsil fixed for varying periods in formalin after an initial 24 hours' fixation at room $60^{\circ} \mathrm{C}$. temperature, $37^{\circ} \mathrm{C}$ or

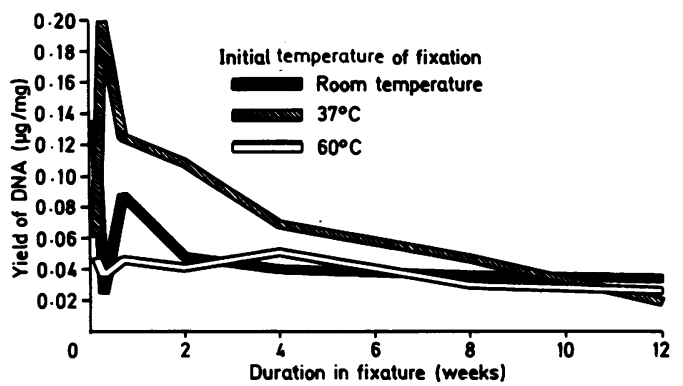

in fixative the yields of DNA extracted from the tissue were low and independent of the initial temperature of fixation.

The yields of DNA extracted from tissue fixed in $4 \%$ formaldehyde and a variety of other commonly used fixatives were compared. Tissue fixed in formaldehyde gave more DNA than tissue fixed in other formaldehyde based fixatives, paraformaldehyde and Bouin's reagent (table 4). The DNA extracted from these tissues was of very low molecular weight (fig 5, lanes 4-8). Surprisingly, it was possible to extract some DNA from material fixed in Bouin's reagent, a picric acid based fixative. Tissue fixed in Carnoy's reagent produced yields of DNA 20 times those from formaldehyde fixed tissue and this DNA was of a much better quality, containing some high molecular weight fragments (fig 5, lanes 2 and 3). DNA PCR of the extracted DNA was successful on five of seven samples, including that fixed in Bouin's reagent. DNA from the tissue fixed in formol sublimate or paraformaldehyde could not be amplified. This may have been due to an inhibition of the $T a q$ polymerase enzyme by one of the constituents of these fixatives-for example, by the mercury contained in formol sublimate.

\section{Discussion}

The use of a quantitative DNA assay has permitted the critical analysis of a variety of DNA extraction techniques and their application to different tissue preparations.

For the extraction of DNA from fresh tissue, we have found that routinely quoted protocols may not be the most efficient as a one hour proteinase $\mathrm{K}$ incubation produces as much DNA as longer incubations. This only partly reduces the time taken for extraction procedures in fresh tissue, however, as the DNA produced by this method is of high molecular weight and may take up to three days to solubilise fully. Of other reported methods, the one hour SDS incubation produces poorer yields of DNA and offers no advantages over

Table 4 DNA yield from $100 \mathrm{mg}$ blocks of tonsil fixed in a range of different fixative agents

\begin{tabular}{llll}
\hline Fixative & $\begin{array}{l}\text { Duration of } \\
\text { fixation (hours) }\end{array}$ & $\begin{array}{l}\text { Mean DNA yield } \\
(\mu g / m g)\end{array}$ & $\begin{array}{l}\text { Mean DNA yield } \\
\text { as a percentage of } \\
\text { optimal method }\end{array}$ \\
\hline Carnoy's & 5 & $2 \cdot 575(3 \cdot 29,1 \cdot 86)$ & 100 \\
Carnoy's & 24 & $1 \cdot 805(1 \cdot 89,1 \cdot 72)$ & 70 \\
Tap water formalin & 24 & $0.089(0 \cdot 11,0.068)$ & 35 \\
Neutral buffered formalin & 24 & $0.061(0.059,0.063)$ & 24 \\
Formol sublimate & 24 & $0.068(0.083,0 \cdot 053)$ & 26 \\
Paraformaldehyde & 24 & $0.063(0.053,0 \cdot 072)$ & 24 \\
Bouin's fixative & 24 & $0.046(0.053,0.039)$ & 18 \\
\hline
\end{tabular}

$\mathrm{n}=2$ : values in parentheses.

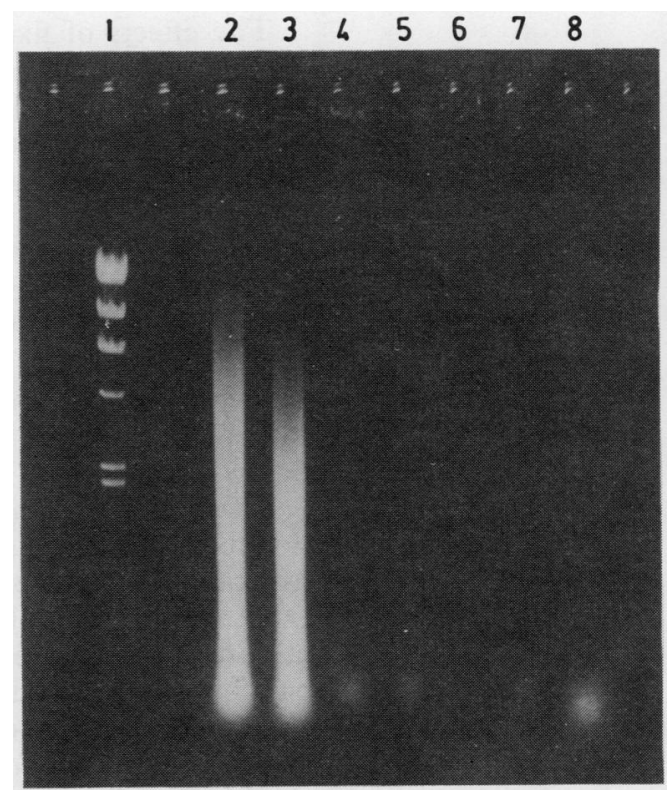

Figure $5 \quad 0.7 \%$ agarose electrophoresis gel of $D N A$ extracted from tissue fixed in different fixative agents by overnight proteinase $K$ incubation. (1) Standard: $\lambda$ DNA Hind III digest; (2) Carnoy's reagent (five hours); (3) Carnoy's reagent (24 hours); (4) tap water formalin; (5) neutral buffered formalin; (6) formol sublimate; (7) paraformaldehyde; (8) Bouin's reagent.

enzyme digestion. While simply boiling tissue is a very rapid procedure that requires no further purification of the DNA, the DNA is not fully dissociated from tissue proteins and the yields of extracted material are low, of poor quality, and unlikely to be suitable for many molecular techniques, with the exception of the polymerase chain reaction.

The extraction of genetic material from paraffin wax embedded tissue is very important as it permits the retrospective molecular investigation of the aetiology and epidemiology of disease. Our study on the effect of fixation procedures on DNA extraction has quantitatively shown that it is the fixation of tissue, rather than any delay in fixation or further processing, which prevents the extraction of high molecular weight DNA using a short proteinase $K$ incubation, as suggested previously. ${ }^{12}$ The yield and quality of DNA from formaldehyde fixed tissue, however, can be improved by increasing the proteinase $K$ digestion to five days. The DNA extracted by this method is likely to be suitable for some molecular techniques and certainly for the amplification of a single copy gene using PCR. DNA samples extracted by this method may require dilution before use with PCR as the amplification may be inhibited by too much template DNA. Alternatively, a product of the fixation or processing procedure may be coextracted along with the DNA, and this may be responsible for the inhibition of amplification, because this effect is not seen with DNA extracted from fresh tissue (unpublished observations). A long proteinase $\mathrm{K}$ digestion is an efficient extraction procedure and is capable of extracting DNA from as little as one paraffin wax embedded section, and so can be used to produce DNA from small quantities of material for PCR analysis. 
The effects of fixation on DNA extraction can be substantially reduced by using a fixative other than formaldehyde. Carnoy's reagent results in a much better preservation of DNA in the tissue, allowing the extraction of high molecular weight $\mathrm{DNA}^{13}$ and quantitatively much higher yields, using more rapid extraction procedures. Although Carnoy's is a poor fixative for histological purposes, it may be potentially useful for the fixation of tissue collected specifically for molecular investigations where low temperature storage is not available.

Although an efficient and sensitive extraction technique, a long proteinase $\mathrm{K}$ incubation may take at least seven days to produce a usable DNA solution. Boiling sections for just 15 minutes produces relatively good yields from paraffin wax embedded tissue and a DNA solution of sufficient concentration to use a $1 \mu \mathrm{l}$ aliquot as template for the amplification of the single copy factor VIII gene. This method, however, is unlikely to produce enough DNA for the investigation of low copy number genetic material as is found in some persistent viral infections. This could be achieved by increasing the sensitivity of the amplification reaction by increasing the number of cycles, although this has the disadvantage of reducing the specificity of the reaction with the production of extraneous bands. Alternatively, a more sensitive autoradiographic detection method could be used, but this would reduce the simplicity and rapidity of the technique. The use of an intact paraffin wax embedded section did not permit amplification of factor VIII, a single copy gene, although it has been used to amplify fragments of the $A l u$ repeat sequence (unpublished results). This suggests that a high copy number of target sequences must be present in the tissue if it is to be used directly as a template for amplification, with no extraction of nucleic acid, using less than 40 cycles of PCR.

RNA extraction procedures tend to be complex to avoid RNAse contamination and have not been described for use with paraffin wax embedded material. We have shown that a relatively simple and convenient technique, involving digestion with proteinase $K$, can extract considerable amounts of RNA from fixed tissue. RNA extracted by this method is suitable for the PCR analysis of viral sequences. ${ }^{13}$ This allows one simple procedure to be used to extract both DNA and RNA from a tissue sample, making more tissue available for molecular investigation.

We thank the Jean Shanks Foundation for supporting D P Jackson. This work was partly funded by grants from the Yorkshire Cancer Research Campaign and the Crohn's Disease in Childhood Research Appeal.

We are indebted to Miss J I Hamblin and Mrs J Fearnley for their help in preparing the manuscript.

1 Strauss WM. Preparation of genomic DNA from mammalian tissue. In: Ausubel FK, Brent R, Kingston RE, et malian tissue. In: Ausubel FK, Brent R, Kingston RE, et al, eds. Current protocols in molecular biology, 1987-8. New York: Greene Publish

2 Maniatis T, Fritsch EF, Sambrook J. Molecular cloning: $A$ laboratory handbook. Cold Spring Harbor Laboratory, New York: Cold Spring Harbor, 1982

3 Goelz SE, Hamilton SR, Vogelstein B. Purification of DNA from formaldehyde fixed and paraffin embedded human tissue. Biochem Biophys Res Commun 1985;130:118-26.

4 Dubeau L, Chandler LA, Gralow JR, Nichols PW, Jones PA. Southern blot analysis of DNA extracted from formalin-fixed pathology specimens. Cancer Res 1986;46:2964-9.

5 Chirgwin JM, Przybyla AE, MacDonald RJ, Rutter WJ. Isolation of biologically active ribonucleic acid from Isolation of biologically active ribonucleic acid from 5294-9.

6 Saiki RK, Scharf S, Faloona F, et al. Enzymatic amplification of $\beta$-Globin genomic sequences and restriction site analysis for diagnosis of sickle cell anaemia. Science 1985;230:1350-4.

7 Hart C, Spira T, Moore J, et al. Direct detection of HIV RNA expression in seropositive subjects. Lancet 1988;ii:596-9.

8 Lynas C, Cook SD, Laycock KA, Bradfield JWB, Maitland NJ. Detection of latent virus mRNA in tissues using the polymerase chain reaction. $J$ Pathol 1989;157:285-9.

9 Hopwood D. Fixation and fixatives. In: Bancroft JD, Stevens A, eds. Theory and practice of histological techniques. 2nd ed. Edinburgh: Churchill Livingstone, niques. 2nd

10 Lench N, Stanier P, Williamson R. Simple non-invasive method to obtain DNA for gene analysis. Lancet method to o

11 Kogan SC, Doherty M, Gitschier J. An improved method for prenatal diagnosis of genetic diseases by analysis of amplified DNA sequences. $N$ Engl J Med 1987;317: 985-90.

12 Burmer GC, Rabinovitch PS, Loeb LA. Analyis of c-Ki-ras mutations in human colon carcinoma by cell sorting, polymerase chain reaction and DNA sequencing. Cancer Res 1989;49:2141-6.

13 Jackson DP, Quirke P, Lewis F, et al. Detection of measles virus RNA in paraffin-embedded tissue. Lancet 1989;i:1391. 